\title{
Architektura cienia
}

\section{Shadow Architecture}

\section{Streszczenie}

O ile w przeszłości światłu w architekturze nieodłącznie towarzyszył cień, zadaniem współczesnego architekta jest zwykle jedynie dbałość o doświetlenie budynku. Brak zacienionych przestrzeni przez stosowanie rozległych przeszkleń i równomiernego, sztucznego oświetlenia to brak tajemnicy - pola dla wyobraźni. Pozbawienie architektury cienia oznacza zatarcie granic pomiędzy wnętrzem i zewnętrzem, dniem i nocą, światem rzeczywistym i wirtualnym oraz nadzór społeczny. Budynki, których twórcy oprócz światła operują także "materią" cienia jako elementem narracji architektonicznej nie są częstymi przykładami. Można do nich zaliczyć realizacje Daniela Libeskinda, Fumihiko Maki, Eduardo Menisa, Stevena Holla. Tworząc odpowiedni nastrój przekazują symboliczne treści.

\begin{abstract}
Whereas in the past shadow was a constant companion of light in architecture, the task of a contemporary architect is usually to care for the lighting of the building. The lack of shaded spaces due to the use of extensive glazing and regular artificial lighting equals the lack of mystery - the field for imagination. Depriving architecture of the shadow means blurring of the boundaries between interior and exterior, day and night, real and virtual world, as well as social supervision. Buildings, whose creators, in addition to light, employ the "matter" of shadow as an element of architectural narrative, are not frequent examples. These include the works of Daniel Libeskind, Fumihiko Maki, Eduardo Menis, Steven Holl. While creating the right mood, they also convey symbolic content.
\end{abstract}

Słowa kluczowe: cień, narracja architektoniczna

Keywords: shadow, architectural narrative

I

Cień w architekturze współczesnej jest konsekwentnie eliminowany. Zjawisko to towarzyszy zmianie form budynków i ich detali. Płaszczyzny ścian historycznych obiektów pocięte prostokątami okien, posiekanymi przez siatki szpros - nieprzejrzyste przegrody z płaszczyznami światła dziennego - są zastępowane przez szklane wypełnienia konstrukcji szkieletowych. Funkcję portyków przejmują ruchome żaluzje. Zanikają bogate obramowania otworów, pilastry, gzymsy, rzeźby, kształtujące formę za pomocą światłocienia.

Zarówno w przestrzeni poszczególnych budynków jak i wnętrzach miejskich, uwaga zwrócona jest na "jasność" - oświetlenie naturalne i sztuczne, białe i kolorowe - tworzące wielobarwne neony informacyjne i reklamowe. Oświetlenie, którego zapewnienie kojarzone jest z wygodą, bezpieczeństwem i nowoczesnością. Cień natomiast należy do świata niepewności i zamierzchłości.

Oświetlenie sztuczne wyparło cień, pozbawiając rzeczywistość magii miejsca, zarówno w świecie zachodnim, jak i na Bliskim oraz Dalekim Wschodzie. Jun'ichir Tanizaki w Pochwale cienia ubolewa nad zanikaniem cienia w Japonii lat trzydziestych XXw. - od zarania dziejów przynależnego japońskiej kulturze ${ }^{1}$. Tanizaki opisuje zamianę tradycyjnego w historycznej Japonii rozległego dachu zacieniającego budynek „parasola” słonecznego - na płaskie zadaszenie pozbawione okapu, który przestaje chronić piękno wnętrz zatopionych w półmroku. Wraz z takimi elementami jak mrok nad belką
I

Shadow is being consistently eliminated in contemporary architecture. This phenomenon accompanies a change in the form of buildings and their details. The planes of the walls in historic structures cut with rectangles of windows, chopped by muntin bars - opaque partitions with planes of daylight - are being replaced by glass panels of a frame construction. Moving elevation screens are taking over the function of porticos. The rich borders of openings, pilasters, cornices and sculptures which used to shape the form by means of light are disappearing.

Both in the space of individual buildings and in urban interiors, attention is focused on "brightness" - natural and artificial, white and colourful lighting - creating multi-coloured information and advertising neon signs. Lighting is associated with comfort, security and modernity while shadow belongs to the world of uncertainty and antiquity.

Artificial lighting has suppressed shadow, depriving reality of the magic of a place, both in the Western world and in the Middle and Far East. In Praise of Shadows, Jun'ichir Tanizaki bemoans the disappearance of shadows in Japan in the 1930s being a part of Japanese culture since the dawn of history ${ }^{1}$. Tanizaki describes the replacement of a traditional wide roof overshadowing the building in historic Japan - the sun "parasol" - for a flat roof without eaves, which no longer protects the beauty of the interior immersed in the dimness. Along with such elements as the murk above the ceiling 
sufitową oraz ciemność pozwalająca wydobyć urodę kobiecą historyczny cień tworzy "tajemniczy swiat Wschodu" - obcy i przerażający dla przybyszów ze świata zachodniego [16]. Współczesna architektura poprzez stosowanie rozległych przeszkleń oraz równomiernego, sztucznego oświetlenia odzwierciedla obecną rzeczywistość - zatarcie granic pomiedzy wnętrzem i zewnetrzem, dniem i noca, rzeczywistym i wirtualnym oraz kontrole - nadzór społeczny. Przemiany te widoczne jest tu zastepowane przez sztuczne, naipierw w formiowo jest tu zastęowane przez sz. Swcre, najplerw w formie elekrzacych nowa rzeczywistość. Zerwanie z opozycja św tworzacych nowa rack strzeni. Miasta XXI wieku przeżywają kryzys metafizyki'.

II

S.E. Rasmussen w Odczuwaniu architektury wskazuje na najbardziej podstawowe działanie cienia - tworzenie efektu plastycznego i fakturowego. „Zbyt jasno oświetlone części unicestwiają formę; natomiast zbyt głęboki cień sprawi, że forma nie będzie z tej strony widoczna" [13, s. 190]. Rasmussen podaje przykład Panteonu jako wnętrza o doskonałym zrównoważeniu światła i cienia, które wydobywają formę, detal i fakturę; wnętrza jednocześnie pozbawionego zaciemnionych miejsc. Prezentuje cień jako istotny i zaplanowany elementem kreowania przestrzeni, opierając swoje argumenty na poetyce malarstwa i scenografii.

Juhani Pallasmaa także przywołuje malarstwo w kontekście znaczącego i koniecznego świattocienia - barokowe obrazy Rembrandta i Caravaggio, w których cień ożywiał elementy umieszczone w świetle, kreując wymiar fantazji. Cytując Pallasmę „mgła i półmrok budzą wyobraźnię, czyniąc obrazy wzrokowe nieostrymi i dwuznacznymi" [11, s. 58].

Według fińskiego architekta głęboki cień i ciemność sa niezbẹdne człowiekowi do egzystencij, jako że rozmywaiąc ostrość widzenia, wprowadzaj niejednoznaczność głebi i odlegtości

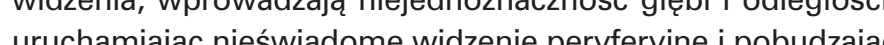
fuchaje Ostrość widzenia natomiast rozjaśni logiczndzając fantazję rownomiene jasne światlo (wsolcos duje paraliz wyobraźni - "Ostabia w Säynätsalo Alvara Aatemne wnętrze sali obrad odzwierciedlić wspólnoty. Przywołuje też słowa Luisa Barragana, zgodnie z którymi duże przeszklenia powoduja utratę poczucia intymności.

Wspólczesne okna oznaczają jedynie nieobecność ściany Element oświetlony jest więc społecznie nadzorowany, niczym w projekcie Panopticonu Jeremy'ego Benthama (1791), w którym nadzorca krył się w cieniu, natomiast więźniowie (czy też nadzorowani) jako elementy do obserwacji musiel znajdować się w pełnym oświetleniu. Element oświetlony to element nadzorowany. Dzisiejsza duża ilość szkła i brak cienia, rzęsiste oświetlenie ulic $w$ miastach to trwanie $w$ kontrol społeczenstwa nadzoru. Powoduje ono we współczesnej kulturze odejście od intymności.

Opozycja światto/cień odpowiada także opozycji znane/nieznane oraz uporządkowane, utworzone/chaotyczne. Rzecz beam and the darkness allowing to emphasize the feminine beauty, the historical shadow created the "mysterious world of the East" - alien and terrifying Through the use of extensive glazing and reger artificial lighting, contemporary architecture reflects the present reality - blurring of the boundaries between interior and exterior, day and night, real and virtual as well as the control - social supervision. These changes are visible in the contemporary city. Natural light is gradually being replaced by artificia as light screens creating the new reality. Abandoning the light/shadow opposition results in the departure from the metaphysical anchoring of space. The 21 century cities experience the crisis of metaphysics

Experiencing Architecture, S.E. Rasmussen points to the most basic impact of the shadow parts are too light the form on that side is killed and if the parts in shadow are too dark no form will be seen there" [13, p. 190]. Rasmussen gives an example of the Pantheon as the interior with a perfect balance of light and shadow that bring out form, detail and texure; the interior simultan shadow as an important and planned element shaping space, basing his arguments on the poetics of painting and stage design.

Juhani Pallasmaa also refers to painting in the context of a meaningful and necessary chiaroscuro Baroque paintings by Rembrandt and Caravaggio the light thus creating the dimension of fantasy. Quoting Pallasmaa: "mist and twilight awaken the imagination by making visual images unclear and ambiguous" [11, p. 50].

According to the Finnish architect, the deep shad ow and darkness are essential to human existence, as their bluring of the sharpness of vision introing unconscious peripheral vision and stimulating fantasy. At the same time, the sharpness of visio brightens logical thinking, regular bright lighting (electrical in our times) leads to imaginary paralysis - "weakens the experience of being".

Further, Pallasmaa describes the town hall in Saynatsalo designed by Alvaro Aalto (1949), where mystical sense of community. He also mentions Luis Barragán's words that large glazing causes a loss of intimacy.

Contemporary windows mean only the absence of walls. An illuminated element is thus socially supervised, as is the case with the Panopticon (1791) man was hiding in the shade, while the inmates (or the supervised ones) as the element for observation had to be in full light. It is therefore the lit element that is the supervised element. Today's larg amount of glass and lack of shadow, the abundan street lighting in cities equals remaining under the departure from intimacy in contemporary culture The light/shadow opposition also corresponds to the known/unknown and organised, created/ chaotic

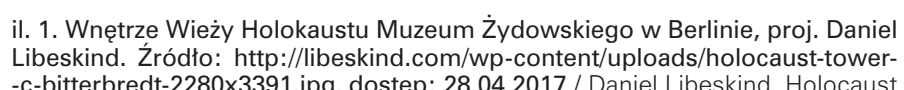

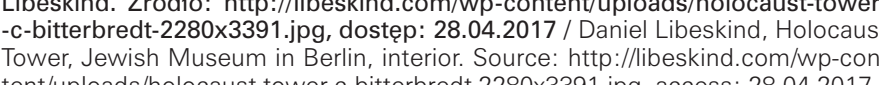

(i przestrzeń) oświetlona to rzecz (i przestrzeń) znana. Transrwanie przestrzeni z objęć mroku. Oświetlone promieniam słonecznymi stają się znajome - w pełni utworzone, uporządkowane za pomocą światła.

Ciemność natomiast odpowiada prachaosowi, ma związek z mityczną Nicością oraz macierzyńskością, zalążkiem rzeczywistości - to "stan potencji nierozwiniętych". Światło jes elementem porzadkowania i hierarchizacji rzeczywistości, jest z siłami zła i niższymi popedami, a według Carla Gusana Junga jest też personifikaja pierwotnej cześci człowieka, warunkowanej popędem [1, s. 98, 99].

Analiza zagadnienia cienia $w$ architekturze współczesnej wy magałaby utworzenia typologii cienia, opartej na jego ontologii oraz historycznej sztuce budowania. Typologia ta obejmowałaby następujące grupy: ciemność, szarówkę, opozycje cień-światło, oraz cień „sączący się" - „smugi cienia”. Do systematyki zagadnienia we wspótczesności należałoby dodac także brak cienia, który w architekturze historycznej (oraz historycznym mieście) nie wystepowat.

Ciemność (aż po ciemność absolutna), której pierwotna forma zaczerpnięta został z grot i jaskiń, niejedokrotnie uznawanych za miea zostala $z$ grot i jaskin, niejedokr wa bowcach, kryptach, piramidach, labiryntach. To przestrzenie kultu fun celu odebranie poczucia bezpieczenstwa - miejsca w ziemi" jako zakończenie ludzkiego żywota. opposition. The thing (and space) illuminated is the thing (and space) known. Thus, the transparency from the cluthes of the darkness. Lit with is freed they become familiar - fully formed, ordered by light. The darkness, on the other hand, corresponds to pre-chaos, it is related to the mythical Nothingness and maternity, the germ of reality - it is a "state of undeveloped potencies". Light is an element of or ness is regressive. Therefore it is is identified with the fores of evil and lower impulses, and, according to Carl Gustav Jung, it is also a personification of the primitive part of man, driven by impulses $[1, \mathrm{pp}$. 98,99

The analysis of shadow in contemporary architecture would require the creation of shadow typology based on its ontology and the historical art of Dinding. This typology would include the following groups: darkness, dusk, shadow-light opposition and "seeping" shadow - "shadow lines". The of shadow of hic did not occur in the histericat a chitecture (and historical city). The darkness (up to the absoluted original form was taken from colute darkess), whose frequently considered sacrem caves and grottoes,

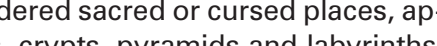
These sense of security - the places of funera away the the space of death, the archetypal "holes in the earth" seen as the end of human life.

The darkness - dusk - is, according to Tadeusz Stawek, the transition between the worlds; an 


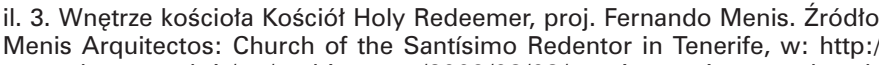

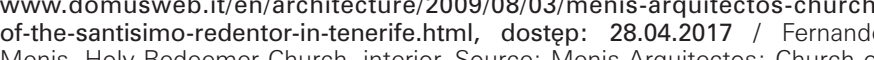

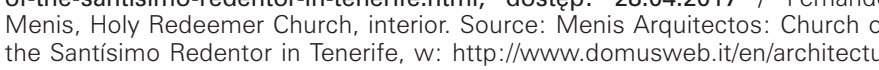
re/2009/08/03/menis-arc
html, access: 28.04-2017

strzenie, horyzont pojednania" [14, s. 117]. Szczeliny okien wpuszczajace światto dzienne do budynku, to tropy adresów mapie Berlina.

déniatto jest zjawiskiem boskim, dajacym nadzieje w ciemnych pomieszczeniach związany niem. Ciemność natomiast zwiqzana jest tutaj z dośmiedzzeWejście do nowej czéci muzeum stanowi zejśc do podziemi - w ciema przestren klatki schodowe jedynie dystretnie ośmietlon śmiettem sztuczny. Wyzaczona przez Libeskinda oś śmierci kończy Wieża Holokaustu - najbardziej dramatyczne miejsce $w$ budynku.

Architekt chciał utworzyć pomieszczenie bez światła i nadziei - najciemniejsze pomieszczenie z budynku, reprezentujące wszystko, co zostało utracone poprzez zagładę Żydów. Wieża jest betonowa, odstawiona od głównego budynku nie ogrzewana ani nie klimatyzowana - opuszczone miejsce, hłód. Ostatecznie jednak otwor na jej szczycie wpuszcza do pomieszczenia linię światta, odbijaną na ścianach i podłodze wewnątrz: „Stan tutaj i zapamiętaj, co możesz. To co pamiętasz jest w świetle, reszta jest $w$ ciemności, nieprawdaż? Przeszłość zaciemnia się, a przyszłość jest nieznana, tylko gwiazdy" [6, s. 139].

Kaze-No-Oka Crematorium projektu Fumihiko Maki (1997) to ciąg lapidarnie kształtowanych przestrzeni w bryłach budynku dyskretnie ukrytych w parku (Maki opierał sie na tradycyjnej dla Japończyków wierze w nastepujace po śmierci człowiek ego powíz - w odróżieniu od bogato zdobionych krematoriów nego - w odrozinieniu od bogato zd

Zmiany światła następują wraz z przejściem do kolejnych Zmiany swiatta następuja wraz z przejsciem do kolejnyc whętrz. Żluzje, klereston we wspołczesnej formie, okn w suficie lub przy podlodze, czy oświetlenie pośrednie $-z$ za-

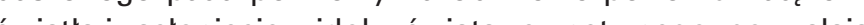
światla i zaslonięcie widoku świata zewnętrznego, pozwalajace na swobodną kontemplację $i$ dające poczucie prywatności. Cląg wewnętrznych przestrzeni budynku, zakonczony zosta osmiokątną kaplicą z difugim, wąskim oknem przy ziemi, ktòre podkreśla mrok w pomieszczeniu. Mrok "gromadzi się" tu przy stropie i rozbity jedynie czterema, okrągłymi, niewielkim świetlikami w suficie.

"Przestrzenie przejścia" zostały podkreślone w budynku. Każ da z funkcji ceremonialnych (pokój oczekiwań, kaplica, cmentarz) oddalona jest od innej, co pozwala na chwilę zadumani $w$ drodze pomiędzy funkcjami. Każdą zamknięto w innej bryle, p. 117]. The slits of windows, which let the daylight into the building, are traces of the addresses of the pre-war domiciles of Jews and Germans on the map of Berlin.

For Libeskind, light is a divine phenomenon, giving hope in the dark rooms associated with imprisonment. Darkness, in turn, is connected here with the new part of the museum is a descent into the underground - into the dark space of the staircase, only discreetly illuminated with artificial light. The death axis designated by Libeskind ends with the Holocaust Tower - the most dramatic place in the building.

The architect wanted to create a room with neither light nor hope - the darkest room in the building 作 of concrete, set of the Jews. The tower is made ther heated nor air conditioned - an abandoned forbidding place where darkness is accompanied by the bitter cold. Ultimately, however, the opening at its top allows the line of light into the room "Stand here and remember whalls and floor inside vou rem is in light the rest is in dakn isn't it? The past fades to dark, and the future is unknown, just stars" [6, p. 139].

Kaze-No-Oka Crematorium designed by Fumihik。 Maki (1997) is a row of succinctly shaped spaces in the body of the building discreetly hidden in the park (Maki based it on the traditional Japa ing their death), in which light acts nature followmetaphysical content and architectural materiat unlike the richly ornamented crematoria built so far in Japan.

in light follow along with the transition to the subsequent interiors. The blinds, a clerestory in a contemporary form, windows i the celing and at the floor level or indirect lighting - from the roofed patio - helped to reduce outside world, allowing for free contemplation and a sense of privacy

The row of interior spaces in the building was completed by an octagonal chapel with a long, narrow window on the ground, which emphasizes the darkness in the room. The darkness "accumulates" here at the celling level and is broken ony by the four small round skylights in the ceiling.
The "transitional spaces" are emphasised in the building. Each of the ceremonial functions (wait ing lounge, chapel, cemetery) is kept at a specific distance from the next one, which allows for a mo- 
ili. 4. Model wnetrag galerii Daeyang Gallery and House,
proj. Steven Holl. Żrodito: In Progress: Daevang Gallery

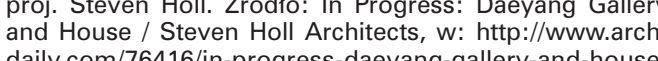

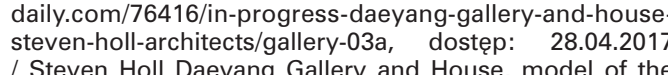
ISteven Holl Doevang Gallery and House, model of the
gallery interior. Source: In Progress: Daevang Gallery and Halery / I Steven Holl Architects, in: http:///www.archdaily.

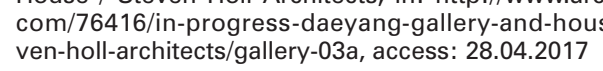

wykończonej innym materiałem. Zadumaniu sprzyja także kolorystyka budynku. Szarości i czerń (kamienia, betonu) w zamierzeniu architekta mają odzwierciedlić "godność", a dodany brąz (stali kortenowskiej) nadać budynkowi łagodności.

Kościół Holy Redeemer (2012) wraz z parafialnym centrum Koscior Holy Rewser (2012) wraz z parafialnym centrum kulturalnym projektu Fernando Menisa w Los Majuelos, San Cristóbal de la Laguna na hiszpańskiej Teneryfie to niewielka bryła o gabarytach pozwalających na wpisanie jej w okoliczną zabudowe mieszkaniową. Betonowe, monolityczne blok formujące budynek, scalone tu zostały za pomocą świetlików, przez które światto dzienne wpada w ciagu dnia pod różnymi kątami w różnych porach dnia, oświetlając kolejno ottarz, konfesjonat, salę centrum parafialnego.

Zacienione fragmenty pozwalają odgrywać świetlnym studniom ich symboliczną rolę - religijnego oświecenia, przejścia od śmierci do życia. Studium promieni słonecznych wpadajacych do budynku w różnych porach dnia ukazuje drogę myślenia architekta - wyrwanie z mroku odpowiednich elementów wskazujące na symboliczne pojęcia: ołtarza - eucharystia, konfesjonału - słowo. Na tle cienia świetlny krzyż, utworzony w odbiciu szczelin wyciętych w ścianie symbolizuje otwarcie w jaskini, gdzie pochowano Chrystusa. Cień gra istotna rolę w projekcie, ukazując również mięsistą
fakture materiałów: betonu, miejscowego kamienia wulkanicznego. Pierwotna w odbiorze przestrzeń, pozbawiona zbędnych elementów kieruje uwagę na przeżycie religijne, któremu przeznaczony jest kościół - zmartwychwstanie. Światło - a wraz z nim cień - odgrywają tu pierwotną rolę, kształtując przestrzeń medytacji.

Smugi cienia kształtuja wnętrze dolnej kondygnacji domu wraz z prywatną galerią koło Seulu, należącego do Daeyang Shipping Company - projektu Stevena Holla (2012). Obiekt składa się z trzech parterowych pawilonów - wejściowego, mieszkalnego oraz zadaszonego tarasu z kuchnią - połączonych na kondygnacjí podziemnej galerią sztuki, przewidziana także jako przestrzeñ rózorodych wydarzen kulturalnych. Strop nad galerią zalewają wody basenu w przestrzeni między pawilonami. Pomieszczenia wewnątrz budynku doświetlane są przez wydłużone prostokąty łącznie 59 świetlików w dnie zbiornika wodnego i na dachach pawilonów. Galeria jest więc zacieniona, a otwory w dnie basenu przepuszczają refleksy słoneczne razem z falującymi cieniami wody. Zmieniają się one bezustannie w rytmie dobowym i rocznym, nadając fenomenologicznych wrazen jednej z istot budynku -„,iałom poruszającym się w przestrzeni"[2].

Galeria została zaprojektowana tak, aby w ciągu dnia nie zachodziła konieczność używania elektrycznego oświetlenia. Zacienione wnetrze wraz $z$ poruszającymi sie refleksami $m$ stanowić przestrzeń idealna. Te $z$ dna basenu maja przypominać muzyczne pauzy, przełamujace ciagłość białych płasz-

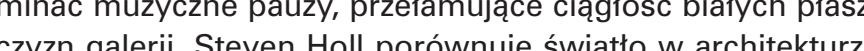
do dźwieku w muzyce - rozkładajace sie w przestrzeni pourze ne jak dzwekwia-

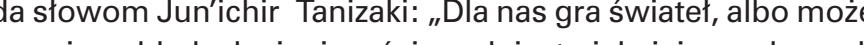
raczej gra bladych cieni na scín ach jest piękniejsza od wsze Scharakery Scharakteryzowanym przyklóm przechstawic mozna zjawisko występujące w większości realizacji architektonicznych (zarowno w poszczegolnych budynkach jak i w przestrzeniach miejskich) - brak cienia, a przynajmniej brak świadomego jego ksztaltowania. Naturalnie pojawiające się przy mniejszym natężeniu swiatta zaciemnienie, jeżeli nie jest celowo eliminowane to przynajmniej „dyskretne" pomijane jako elementu niepożądanego.

$\mathbf{v}$

W opisanych powyżej przykładach cień jako zabieg poetyki architektury otrzymuje rożnorodne znaczenia, na ktore wskazują ich twórcy oraz analiza obiektów: nieobecność, trauma żałoba, religijne oświecenie, sacrum sztuki, nastrojowośc i metafizyczne doświadczenie upływu czasu.

Oprócz budynków sakralnych oraz miejsc związanych z sacrum sztuki, cień jako świadomy zabieg przestrzenny wprowadzony został do przestrzeni współczesnego domu. W Daeyang Gallery and House - gdzie według architekta muzyka malarstwo, rzeźba i poezja stały sie fundamentem domowe malarstwo, ŕcíc to i poczac swoista miniutopie" - smugi cienie za składo fenomen y: Dom jest domem duszy, serca i ducha. Jest pojemnikiem

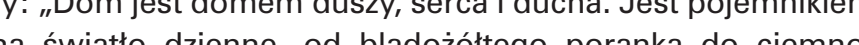
ni niebieskjego potrek. Jest pudekiem na egzystencjalne obiekty zycia. Jest naczyniem na wyobrażnię, smiech i ruch Opisane przykłady oraz zawarte $w$ artykule myśli m.in. Juhaniego Pallasmy, Steena Eilera Rasmussena czy Jun 'ichir Tanizakiego wskazują na koniecznosc uwzględnienia cienia w architekturze wspolczesnej. Podobnie jak światio jako zjawisko kreujące przestrzeń ma charakter uniwersalny -międzydyskursywny i międzykuturowy - ciemnosc jest srodkiem narracyjnym w budynkach o różnorodnych funkcjach: krematoriach, kosciołach, muzeach, domach. Prezentuje metafizyczne treści. W opozycji światło/cień konieczna jest jej obecnośc jako wyrażenie przestrzeni chaosu, praciemności sił, nieobecności, sił pierwotnych, potencjału.

Według Maurice'a Merleau-Ponty zacieniona przestrzen w pełni ukazuje swoją istotę dopiero $w$ momencie wejści W nią: „cień staje się naprawdę cieniem (...) dopiero wtedy gdy przestaje leżeć przed nami jako coś, co można widziec,
The pool water floods the ceiling above the gallery in the space between pavilions. The interior of the building is illuminated by elongated rectangles pool and on the roofs of the pavilions. The of the is therefore shaded, and the holes in the bottom of the pool let the sunlight in along with the rippling shadows of the water. They change constantly in the daily and annual rhythms, granting phenom enological impressions to one of the building's esences - "bodies moving in space"[2].

The gallery was designed so that no electrical lightinterior with moving reflections is intended as the ideal space. The ones in the bottom of the pool are supposed to resemble musical pauses, breaking the continuity of the gallery's white planes. Steven th mumpares the light in architecture to the sound time. The interior of the Korean as does cound in to Jun'ichir Tanizaki's words: "We never tire of the sight, for to us this pale glow and these dim shadows far surpass any ornament" [16, p. 40]. The above characterized examples can be contrasted with the phenomenon that occurs in mos buildings and in urban spaces) - the lack of shadow, or at least lack of conscious shaping of it The darkness which occurs naturally with less light intensity, if not intentionally eliminated, is at leas "discretely" neglected as an undesirable element.

$\mathrm{V}$

In the above described examples, the shadow as a measure of architectural poetics is given a varithe mourning religious enlightenment, the sacred in art, mood and metaphysical experience of the passage of time.

In addition to sacred buildings and places associated with the sacred in art, shadow as a conscious spatial measure was introduced into the space of House - where, according to the architect, music painting, sculpture and poetry became the foundation for home reality, creating a particular "miniutopia" - the shadow lines are a component of the phenomenological experience of architecture: "The house is a home for the soul, the heart and the pale yellow of dawn to the deep blue of twilight is a box for the essential objects of life. It is a vesse for imagination, laughter, and emotion... and a silent space for the poetic sense of life." [3, p. 63] The above discussed examples and reflections from, among others, Juhani Pallasmaa, Steen Eiler

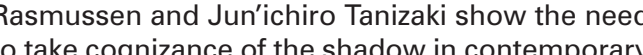
architecture. Just as light as a phenomenon creating space has a universal character - interdiscursive and intercultural one - darkness is a narrative device in buildings of various functions: crematoria, churches, museums, houses. It presents metaphysical content. In the light/shadow opposition space of chaos, pre-darkness, absence, primordia forces and potential. 
i gdy nas otacza, gdy staje się naszym środowiskiem, w którym się urządzamy"[10, s. 335]. Według Merleau-Ponty stałość bieli staje się doskonała dopiero, kiedy wkraczamy w strefę cienia. Cień więc jako środowisko pozwala zobaczyć rzeczywisty kolor i słońce. Jest elementem „praciemności”, stanowiącej tło dla twórczej mocy światła. Wskazuje jasność, pozwala określić czas. Kreuje przestrzeń spokoju, mistyczności, zadumy.

O ile możliwe jest odnalezienie realizacji budynków, w których cień pojawia się w architekturze, ciemność nie jest elementem planowanym we współczesnym mieście. Wymogi bezpieczeństwa warunkują oświetlenie przestrzeni miejskich. Nie bez znaczenia jest także kojarzenie miasta jako wytworu kultury - uporządkowanego, w pełni wytworzonego, a więc ogarniętego światłem, symbolem pierwiastka intelektualnego.

Jednak cień-ciemność jako element pierwotny, element prachaosu musi znaleźć swoje miejsce w otaczającym świecie. W kulturze zachodniej, podobnie jak w magicznym świecie wschodu, według Jun’ichiro Tanizakiego: „nie ma piękna bez cienia” [16, s. 58].

\section{PRZYPISY:}

1 Pochwała cienia pochodzi z 1933 roku. Jak zauważa Henryk Lipszyc, tłumacz i autor przedmowy, już wtedy problem zaniku cienia był widoczny [16, s. 8]

2 Zjawisko oraz jego genezę i następstwa opisała Ewa Rewers [14, s. 101-143]

"Holl używa określenia "fingers of light". Podobną opozycję światło-cień i rozważania na temat jego natury ilustruje zdjęciem domu swojego projektu w Martha's Vineyard [4, s. 62, 63].

\section{LITERATURA:}

[1] Cirlot, J.E., Stownik symboli, Kraków, Wydawnictwo Znak 2006

[2] Daeyang Gallery and House: A Conversation with Steven Holl [w:] https://vimeo.com/45441531 [dostęp: 27.04.2017]

[3] Futagawa Y., Steven Holl: 1975-1998, Volume 1, Tokyo, Edita 2012.

[4] Holl S., Pallasmaa J., Pérez-Gómez A., Questions of Perception: Phenomenology of Architecture, William Stout 2007

[5] Holy Redeemer Church [w:] http://menis.es/holy-redeemer-church/ [dostęp: 27.04.2017]

[6] Kennicott P., Music Holl: A Copper Clad Pavilion in Seoul [w:] http:// www.dwell.com/house-tours/article/music-holl-copper-clad-pavilionseoul [dostęp: 27.04.2017]

[7] Libeskind D., Breaking Ground: An Immigrant's Journey from Poland to Ground Zero, Riverhead Books 2004.

[8] Lefevbre H., The Production of Space, Blackwell Publishing, Malden Oxford Victoria 1991.

[9] Menis Arquitectos: Church of the Santísimo Redentor in Tenerife, [w:] http://www.domusweb.it/en/architecture/2009/08/03/menis-arquitectos-church-of-the-santisimo-redentor-in-tenerife.html [dostęp: 27.04.2017].

[10] Merleau-Ponty M., Fenomenologia percepcji, Warszawa, Fundacja Aletheia 2001

[11] Pallasmaa J., Oczy skóry - architektura i zmysły, Kraków, Instytut Architektury 2012.

[12] Naomi R. Pollock, Kaze-No-Oka Crematorium, [w:] Architectural Record, nr 2, 1998, s. 92-100.

[13] Rasmussen S.E., Odczuwanie architektury, Warszawa, Wydawnictwo Murator 1999.

[14] Rewers E., Post-polis, wstep do filozofii ponowoczesnego miasta, Kraków, Universitas 2005.

[15] Sławek T., Miasto. Próba zrozumienia, [w:] Miasto w sztuce - sztuka miasta, red. Rewers E., Kraków, Universitas 2010, s. 17-69.

[16] Tanizaki J., Pochwała cienia, Kraków, Wydawnictwo Karakter 2016.
According to Maurice Merleau-Ponty, shaded space fully reveals its essence only when one enters it: "The shade does not become really a shade (...) until it has ceased to be in front of us as something to be seen, but surrounds us, becoming our environment in which we establish ourselves"[10, p. 335]. According to Merleau-Ponty, the constancy of the white becomes perfect only when we enter the shady zone. Thus, the shade as the environment allows one to see the actual colour and sun. It is the element of "pre-darkness" which constitutes the background for the creative power of light. It indicates brightness, lets one determine the time. It creates a space of calmness, mysticism and reflection.

While it is possible to find such buildings in which shadow appears in architecture, darkness itself is not an element planned in the contemporary city. Urban space lighting is conditioned by safety requirements. Also, associating the city as a product of culture is not without significance here - the city which is organised, fully formed, and therefore, embraced by light, the symbol of intellectual element.

However, the shadow-darkness as the primordial element, the element of pre-chaos, must find its place in the surrounding world. According to Jun'ichiro Tanizaki, both in Western culture and in the magical world of the East: "were it not for shadows, there would be no beauty" [16, p. 58].

\section{ENDNOTES:}

1 Praise of Shadows dates back to 1933. As noted by Henryk Lipszyc, the translator and author of the preface, it was already at that time that the problem of the disappearance of shadow was visible [16, p. 8].

2 The phenomenon, its genesis and consequences were described by Ewa Rewers [14, pp. 101-143]

${ }^{3}$ Holl illustrates a similar light-shadow opposition and reflections on its nature with the picture of the house he designed in Martha's Vineyard $[4$, pp. 62,63].

\section{BIBLIOGRAPHY:}

Cirlot, J.E., Słownik symboli, Kraków, Wydawnictwo Znak 2006. [1] Cirlot, J.E., Słownik symboli, Kraków, Wydawnictwo Znak 2006. [2] Daeyang Gallery and House: A Conversation with Steven Holl [w:] https://vimeo.com/45441531 [dostęp: 27.04.2017]

[3] Futagawa Y., Steven Holl: 1975-1998, Volume 1, Tokyo, Edita 2012.

[4] Holl S., Pallasmaa J., Pérez-Gómez A., Questions of Perception: Phenomenology of Architecture, William Stout 2007.

[5] Holy Redeemer Church [w:] http://menis.es/holy-redeemerchurch/ [dostęp: 27.04.2017]

[6] Kennicott P., Music Holl: A Copper Clad Pavilion in Seoul [w:] http://www.dwell.com/house-tours/article/music-holl-copper-cladpavilion-seoul [dostęp: 27.04.2017]

[7] Libeskind D., Breaking Ground: An Immigrant's Journey from Poland to Ground Zero, Riverhead Books 2004

[8] Lefevbre H., The Production of Space, Blackwell Publishing, Malden Oxford Victoria 1991.

[9] Menis Arquitectos: Church of the Santísimo Redentor in Tenerife [w:] http://www.domusweb.it/en/architecture/2009/08/03/menis-arquitectos-church-of-the-santisimo-redentor-in-tenerife.html [dostęp: 27.04.2017].

[10] Merleau-Ponty M., Fenomenologia percepcji, Warszawa, Fundacja Aletheia 2001

[11] Pallasmaa J., Oczy skóry - architektura i zmysty, Kraków, Instytut Architektury 2012.

[12] Naomi R. Pollock, Kaze-No-Oka Crematorium, [w:] Architectural Record, nr 2, 1998, s. 92-100.

[13] Rasmussen S.E., Odczuwanie architektury, Warszawa, Wydawnictwo Murator 1999.

[14] Rewers E., Post-polis, wstęp do filozofii ponowoczesnego miasta, Kraków, Universitas 2005.

[15] Sławek T., Miasto. Próba zrozumienia, [w:] Miasto w sztuce - sztuka miasta, red. Rewers E., Kraków, Universitas 2010, s. 17-69.

[16] Tanizaki J., Pochwała cienia, Kraków, Wydawnictwo Karakter 2016. 